\section{Barriers to Adopting Sustainable Floriculture Certification}

\author{
Tanya J. Hall ${ }^{1}$ and Roberto G. Lopez ${ }^{2,5}$ \\ Department of Horticulture and Landscape Architecture, Purdue University, \\ 625 Agriculture Mall Drive, West Lafayette, IN 47907
}

\author{
Maria I. Marshall ${ }^{3}$ \\ Department of Agricultural Economics, Purdue University, 403 West State \\ Street, West Lafayette, IN 47907
}

\begin{abstract}
Jennifer H. Dennis ${ }^{4}$
Departments of Agricultural Economics and Horticulture and Landscape Architecture, Purdue University, 625 Agriculture Mall Drive, West Lafayette, IN 47907
\end{abstract}

Additional index words. attitudes, grower perceptions, logistic regression, risk, survey

\begin{abstract}
In recent years, the commercial greenhouse industry has begun to implement sustainable production practices. However, floriculture certification programs for sustainable production practices are a relatively new phenomenon in the United States. Between July and Oct. 2008, a commercial floriculture grower survey was conducted to determine potential barriers to sustainable floriculture certification. Using a logistic regression model, seven potential areas were evaluated: risk, profitability, economic viability, prior experience, education, operation size, and customer types. Although respondents had positive attitudes toward sustainability and had adopted sustainable practices, respondents had little knowledge and interest in U.S. certification.
\end{abstract}

The commercial floriculture industry in the United States includes bedding and garden plants, potted flowering and foliage plants, propagative material, cut flowers, and cut cultivated greens (USDA, 2008). Most floriculture crops are produced under 76 million square meters (7617 ha) of controlled greenhouse environments or other protected structures (USDA, 2008, 2009).

The high use of petroleum-based products to produce floriculture crops has been criticized in the mainstream media, thus spurring discussions about sustainable floriculture production (Botts, 2007; Krug et al., 2008; Stewart, 2007). A definition for sustainable floriculture production has been developed by the Floriculture Sustainability Research Coalition (Krug et al., 2008). It states that sustainable floriculture production aims to reduce environmental degradation, maintain agricultural productivity, promote economic

\footnotetext{
Received for publication $1 \mathrm{Feb} .2010$. Accepted for publication 9 Mar. 2010.

We gratefully acknowledge funding from the Ball Horticultural Company and Purdue University's Mission Oriented Grant, growers providing support for Purdue University floriculture research, and numerous state associations and trade press who promoted the survey.

${ }^{1}$ Former graduate student.

${ }^{2}$ Assistant Professor of Horticulture and Landscape Architecture.

${ }^{3}$ Associate Professor of Agricultural Economics.

${ }^{4}$ Associate Professor of Agricultural Economics and Horticulture and Landscape Architecture.

${ }^{5}$ To whom reprint requests should be addressed; e-mailrglopez@purdue.edu.
}

viability, conserve resources and energy, and maintain stable communities and quality of life (Krug et al., 2008). Examples of sustainable practices include recycling irrigation water and plastic, implementing biological controls, and using alternative energy sources (Lopez et al., 2008).

Retailers, wholesalers, and consumer demand have begun to pressure the U.S. floriculture industry to become more sustainable (Stewart, 2007). It is also believed that the demand for organic and sustainable flower products is increasing in the United States as a result of an emerging market segment focused on health and fitness, the environment, personal development, sustainable living, and social justice, known as Lifestyles of Health and Sustainability (LOHAS) (Lifestyles of Health and Sustainability, 2009; Stewart, 2007). The LOHAS market represents $30 \%$ of all U.S. households and is spending \$230 billion annually on socially and environmentally responsible products (Stewart, 2007). In 2005, the $\$ 16$ million organic flower market was the fastest growing sector of the nonfood organic market in the United States (Lifestyles of Health and Sustainability, 2009).

Currently, the vast majority of floriculture crops or cut flowers sold in the United States are not labeled as sustainably or organically produced. However, flower identity can be enhanced through "green label" flower certification programs, establishing standards for the reduction of pesticides and other chemicals, conservation of natural resources, worker safety, and labor rights (Stewart, 2007). In recent years, there has been a marked increase in the number of voluntary certification programs for consumer products worldwide. This increase is evidenced by the rapid growth of ecolabels in the marketplace, which have grown from only a dozen programs in the 1990s to over an estimated 415 at present (Delmas and Grant, 2008). Ecolabels signal the environmental attributes of a product to a consumer through simple and easily interpretable information and try to elicit increased demand for products perceived as environmentally favorable (Delmas and Grant, 2008; Fischer et al., 2005; Lohr, 1998). Examples of ecolabels include the Forest Sustainable Stewardship label for lumber and the Energy Star label for household appliances (Delmas and Grant, 2008). These ecolabels are the result of firms adopting nonmandatory approaches toward environmental protection by registering with a certifying organization that grants the approval of the ecolabel on the product (Delmas and Grant, 2008; Fischer et al., 2005; Khanna, 2001; Lohr, 1998).

Adoption can be considered a mental process that begins when an individual or operation learns of an innovation such as sustainable practices and ends at the final adoption stage of certification, considered as allocation of resources toward implementation (Rogers, 1962). Barriers to adopting sustainable floriculture certification can be defined as factors that prevent growers from adopting a new technology, practice, or innovation (Wilkening, 1953). Examples of these barriers could include cost of technology, lack of incentive, lack of knowledge, age, level of education, and risk perceptions (Banerjee et al., 2008; Barreiro-Hurle et al., 2008; D'Souza et al., 1993; Gillespie et al., 2004; Hattam, 2006; Paudel et al., 2008; Ward et al., 2008).

A great deal of research has been conducted regarding the barriers to adoption in agricultural industries, including cow-calf (Ward et al., 2008), dairy (Paudel et al., 2008), cotton (Banerjee et al., 2008), seafood (Gillespie and Lewis, 2008), soybeans (Fernandez-Cornejo et al., 2005), rice (Annou et al., 2005), and hog production (Gillespie et al., 2004). Various studies have evaluated the adoption of new technology practices (Annou et al., 2005; Banerjee et al., 2008; Fernandez-Cornejo et al., 2005; Gillespie and Lewis, 2008; Gillespie et al., 2004) and factors affecting adoption of new practices (Paudel et al., 2008; Ward et al., 2008). Likewise, studies on the implications of certification programs in the food and lumber industries are expanding with several addressing adoption of certification systems (Bulut and Lawrence, 2007; Delmas and Grant, 2008; Fischer et al., 2005; Greene, 2001; Greene and Kremen, 2003; Lohr, 1998). However, this research is believed to be the first to address the adoption of sustainable floriculture certification by greenhouse growers.

Within the international floriculture industry, certification programs for environmentally friendly practices are still a relatively new phenomenon. In the mid-1990s, the European floriculture industry began developing certification programs to eliminate the anonymity of cut flower grower practices (Stewart, 2007). 
Today, eight floriculture certification programs exist internationally to promote environmental stewardship, or sustainable production, as well as fair trade and fair labor practices for employees (Bauer, 2007; Fair Labeling Organization International, 2008)

In the United States, the presence of certification programs for floriculture products are very recent. The Veriflora ${ }^{\circledR}$ program began certifying operations in 2007 and Milieu Project Sierteelt (MPS) certified their first operation in 2008 (Milieu Project Sierteelt, 2009; Veriflora $\left.{ }^{\circledR}, 2009\right)$. Veriflora ${ }^{\circledR}$ and MPS offer similar services to customers but differ in their certification processes. Located in the United States, the Veriflora ${ }^{\circledR}$ certification program is for growers and handlers of fresh cut flowers and potted plants and evaluates each operation based on its environmental, economic, and social sustainability as well as product integrity (Veriflora ${ }^{\circledR}, 2009$ ). Based in The Netherlands, MPS targets entrepreneurs in the floriculture, bulb, nursery stock, and vegetable sectors (Milieu Project Sierteelt, 2009).

The steps taken by the growers to become certified and how the growers are "graded" on their sustainable practices also differ between Veriflora ${ }^{\circledR}$ and MPS. Veriflora ${ }^{\circledR}$ focuses on eight categories for certification: sustainable crop production, ecosystem management and protection, resource conservation and energy efficiency, integrated waste management, fair labor practices, community benefits, product quality, and product safety and purity (Veriflora ${ }^{\circledR}, 2009$ ). MPS' approach to certification is based on four categories: crop protection agents, waste, energy, and fertilizers (Milieu Project Sierteelt, 2009). MPS' approach only evaluates the production aspect of the business, whereas Veriflora ${ }^{\circledR}$ also examines the treatment of workers and the business' impact on the community.

Sustainability and sustainable floriculture certification is a new development in the floriculture industry; therefore, peer-reviewed research on this topic is limited. The objective of this study was to determine existing barriers to the adoption of sustainable floriculture certification by greenhouse growers, including growers' perceptions on how certification will affect the operation's economic viability, risk of sustainable production practices, prior sustainability experience, demographic variables, and customer types. To our knowledge, previous studies have not looked at the influence of customer type on a grower's decision to become certified.

\section{Materials and Methods}

A national convenience sample of floriculture growers was surveyed between June and Oct. 2008. Identical surveys were administered in three ways: in person, by mail, and through the Internet. These multiple outreach methods were developed to improve the response rates of the survey, because research has shown that repeated contact improves response rate (Dillman, 2007).

The paper survey was distributed to growers at the 2008 Ohio Florist Association
(OFA) Short Course, the DS Cole Growers open house, and at the Indiana Flower Growers Association annual conference. The Internet version of the survey was promoted at the OFA Short Course and to national horticultural associations to increase grower response, thus providing another convenient way to complete the questionnaire. A total of 86 horticultural associations in 46 states were contacted to assist in promoting the survey to their members, and 16 state associations assisted in the promotion. Two states (Indiana and California) provided addresses for their members, and the questionnaire was mailed to these growers The floriculture trade press was also contacted and brief articles were run to promote the survey. Trade press outlets included: Ball Publishing GreenTalks, Greenhouse Grower Benchrunner, Greenhouse Management and Production Project: Green Industry, and Greenhouse Product News weekly. These trade press outlets were chosen because they are the major trade press outlets in the floriculture industry and widely read by growers.

The questionnaire solicited information relating to the importance of sustainability, sustainable practices currently in place, sustainable practices respondents would like to implement in the future, and respondent knowledge of existing certification programs. Questions concerning grower attitudes and perceptions toward profitability, risk, certification, and other factors that would influence their decision to become certified were also included. Respondents were asked to provide the square footage of their operation, gross sales, number of employees, crops grown, customer groups, number of years in the floriculture industry, age, educational level, and zip code. A total of 112 surveys were collected and used for analysis in SPSS 16.0 (SPSS Inc., Chicago, IL).

As a result of the dichotomous dependent variable, a binary logistic regression was used (Liao, 1994). The logistic regression can be explained mathematically through the generalized linear model (Liao, 1994). The econometric approach assumes an underlying response variable $\mathrm{y}^{*}$ defined by the regression relationship:

$$
y^{*}=\sum_{k=1}^{K} \beta_{k} x_{k}+\varepsilon,
$$

where $\mathrm{y}^{*}$ is generally unobserved and $\varepsilon$ is symmetrically distributed with zero mean (Liao, 1994). The dependent variable, $\mathrm{y}^{*}$, is defined as:

$$
y=\left\{\begin{array}{l}
1 \text { if } y^{*}>0 \\
0 \text { otherwise }
\end{array}\right.
$$

The parameter estimates $(\beta)$ are used to predict the log odds (logit) of the dependent variable (z). Thus, following Garson (2009), the prediction equation is:

$$
\begin{aligned}
z & =\ln (\text { odds }(\text { event })) \\
& =\ln \left(\frac{\operatorname{prob}(\text { event })}{\text { prob }(\text { nonevent })}\right) \\
& =\ln \frac{(\text { prob }(\text { event }))}{[1-\text { prob }(\text { event })]} \\
& =b_{0}+b_{1} X_{1}+b_{2} X_{2}+\cdots+b_{k} X_{k} .
\end{aligned}
$$

The binary logistic model for this study regressed the dependent variable, $\mathrm{z}$, of whether the grower was interested in sustainable floriculture certification against the variables that may influence floriculture certification.

$$
z=\left\{\begin{array}{l}
1: \text { interested in certification } \\
0: \text { otherwise }
\end{array}\right.
$$

Thus, the model can be expressed as follows:

$$
\begin{aligned}
z= & \beta_{0}+\beta_{1} \text { risky }+\beta_{2} \text { captinvst }+\beta_{3} \text { noprofit } \\
& +\beta_{4} \text { objres }+\beta_{5} \text { usetepr }+\beta_{6} \text { allretail } \\
& +\beta_{7} \text { allwhole }+\beta_{8} \text { custoth }+\beta_{9} \text { age } \\
& +\beta_{10} \text { sizegl } 5+\beta_{11} \text { highschool. }
\end{aligned}
$$

\begin{tabular}{|c|c|c|}
\hline Variable & Description & Variable scale \\
\hline risky & $\begin{array}{l}\text { Perception that converting to sustainable } \\
\text { practices is risky }\end{array}$ & $1=$ strongly disagree, $7=$ strongly agree \\
\hline captinvst & $\begin{array}{l}\text { Whether paying up to } \$ 5000 \text { would } \\
\text { influence decision to become certified }\end{array}$ & $1=$ no effect, $5=$ significant effect \\
\hline noprofit & $\begin{array}{l}\text { Perception that becoming sustainable } \\
\text { will not generate profits for the operation }\end{array}$ & $1=$ strongly disagree, $7=$ strongly agree \\
\hline objres & $\begin{array}{l}\text { Whether objective industry research on } \\
\text { certification and profitability would } \\
\text { influence decision to become certified }\end{array}$ & $1=$ no effect, $5=$ significant effect \\
\hline usestpr & Grower has adopted sustainable practices & $1=$ yes, $0=$ otherwise \\
\hline allretail & $\begin{array}{l}\text { Grower sells to mass merchandiser, } \\
\text { supermarkets, or other form of retailer }\end{array}$ & $1=$ yes, $0=$ otherwise \\
\hline allwhole & $\begin{array}{l}\text { Grower sells to either a wholesaler, a } \\
\text { broker, or to other growers }\end{array}$ & $1=$ yes, $0=$ otherwise \\
\hline custoth & $\begin{array}{l}\text { Grower sells to landscapers, farmers markets, } \\
\text { independent greenhouses, and other }\end{array}$ & $1=$ yes, $0=$ otherwise \\
\hline age & Age of grower & $1=$ older than $54,0=$ otherwise \\
\hline sizegl5 & Size of operation & $1=$ greater than 5 acres, $0=$ otherwise \\
\hline highschool & Education level of grower & $\begin{array}{l}1=\text { high school degree and above, } \\
0=\text { otherwise }\end{array}$ \\
\hline
\end{tabular}

Descriptions for each explanatory variable can be found in Table 1 . The customer reference variable is cash and carry customers compared with retail, wholesale, and other customers.

Table 1. Description and scale of variables used in the logistic regression model. 


\section{Results and Discussion}

Demographic characteristics of floriculture growers and operations. Respondents of the survey ranged in age from 27 to 72 years old with a mean age of 57 years and were predominantly male $(62.5 \%)$, college graduates (79.5\%), and Caucasian (92.9\%) (Table 2). Demographics of the operations are described in Table 3. Nearly half (48.2\%) of the growers were from the Midwest. On average, respondents classified themselves as wholesalers $(35.7 \%)$ or growers $(34.6 \%)$ who predominantly grew bedding plants $(28.0 \%)$. They identified their primary customer group as cash and carry customers (26.9\%) followed by landscapers/independent garden centers (20.4\%). In 2007, $42.9 \%$ of growers had gross sales over $\$ 1$ million. The majority of growers $(57.1 \%)$ had a covered greenhouse production area of less than 1 acre (less than 43,560 square feet) with a median size of 30,000 square feet.

Knowledge of sustainable floriculture practices and certification programs. Nearly $96 \%$ of respondents were aware of sustainable floriculture and the majority $(65.2 \%)$ viewed sustainable practices as "very important" to the environment. Sixty-three percent of growers had already adopted sustainable practices in their operations and $24.3 \%$ were in the process of adopting sustainable practices. However, the majority $(62.0 \%)$ of respondents were not interested in becoming certified. Sixty percent of respondents had heard of Veriflora ${ }^{\circledR}$ and $21.6 \%$ had heard of MPS; however, $37.8 \%$ had not heard of either program. Respondents also indicated that they had either very little or no knowledge about either U.S. sustainable floriculture cer-

Table 2. Demographic characteristics of respondents that participated in the survey.

\begin{tabular}{lrr}
\hline & $\begin{array}{c}\text { Number of } \\
\text { respondents }\end{array}$ & $\begin{array}{r}\text { Percent of } \\
\text { respondents }\end{array}$ \\
\hline Age of respondents (years) & & \\
70 to 79 & 4 & 3.6 \\
60 to 69 & 10 & 8.9 \\
50 to 59 & 45 & 40.2 \\
40 to 49 & 24 & 21.4 \\
30 to 39 & 18 & 16.1 \\
20 to 29 & 6 & 5.3 \\
Did not respond & 5 & 4.5 \\
Gender & & \\
Male & 70 & 62.5 \\
Female & 39 & 34.8 \\
Did not respond & 3 & 2.7 \\
Education level & & \\
High school & 5 & 4.5 \\
graduate & & \\
Some college & 16 & 14.2 \\
College graduate & 64 & 57.1 \\
Master's degree & 18 & 16.1 \\
Doctoral degree & 7 & 6.3 \\
Did not respond & 2 & 1.8 \\
Ethnicity & & \\
African & 1 & 0.9 \\
Caucasian or & 104 & 92.9 \\
European & & \\
Asian & & 0.9 \\
Other & 3 & 2.7 \\
Did not respond & 3 & 2.7 \\
\hline & & \\
& & \\
\hline
\end{tabular}

Table 3. Demographic characteristics of respondents' operations.

\begin{tabular}{|c|c|c|}
\hline & $\begin{array}{l}\text { Number of } \\
\text { respondents }\end{array}$ & Percent \\
\hline \multicolumn{3}{|l|}{ Size (gross sales) } \\
\hline Less than $\$ 100,000$ & 28 & 25.0 \\
\hline$\$ 100,001$ to 250,000 & 15 & 13.4 \\
\hline$\$ 250,001$ to 500,000 & 7 & 6.3 \\
\hline$\$ 500,001$ to 1 million & 8 & 7.1 \\
\hline$\$ 1,000,001$ to 2 million & 12 & 10.7 \\
\hline$\$ 2,000,001$ to 5 million & 11 & 9.8 \\
\hline$\$ 5,000,001$ to 10 million & 9 & 8.0 \\
\hline$\$ 10,000,001$ to 20 million & 11 & 9.8 \\
\hline Greater than $\$ 20$ million & 5 & 4.5 \\
\hline Did not respond & 6 & 5.4 \\
\hline \multicolumn{3}{|l|}{ Size (square footage converted to acres) } \\
\hline 0 to 1 acres & 64 & 57.1 \\
\hline 1 to 5 acres & 13 & 11.6 \\
\hline 5 to 10 acres & 13 & 11.6 \\
\hline 10 acres + & 15 & 13.4 \\
\hline \multirow[t]{2}{*}{ Did not respond } & 7 & 6.3 \\
\hline & Mean & SD \\
\hline \multicolumn{3}{|l|}{ Operation type $\mathrm{z}^{\mathrm{z}}$} \\
\hline Percent as wholesaler & 35.7 & 40.7 \\
\hline Percent as grower & 34.6 & 39.2 \\
\hline Percent as retailer & 23.8 & 32.2 \\
\hline \multicolumn{3}{|l|}{ Customer type ${ }^{z}$} \\
\hline Percent cash and carry & 26.9 & 38.9 \\
\hline Percent landscapers/independent garden center & 20.4 & 31.9 \\
\hline Percent wholesale retailers & 14.7 & 27.1 \\
\hline Percent other growers & 8.0 & 39.2 \\
\hline Percent mass merchandisers & 7.8 & 22.0 \\
\hline Percent retail florists & 6.3 & 17.8 \\
\hline Percent supermarket chains & 5.6 & 15.6 \\
\hline
\end{tabular}

${ }^{\mathrm{z}}$ Growers ranked all categories that applied to operation.

tification program. However, they did indicate having more knowledge about Veriflora ${ }^{\circledR}$ than MPS. The descriptive statistics of participants' perception of certification are shown in Table 4.

Significant factors affecting willingness to adopt. The binary logistic model was a good fit for the data $\left(\chi^{2}=29.17, P=0.002\right)$ correctly predicting $76.3 \%$ of the observations. Five variables were statistically significant in the model: conversion to sustainable floriculture as risky, sustainability will not generate profits for operation, objective research on how certification can improve profitability, retail customers, and direct customers. The logistic regression results are shown in Table 5.

Risk. Jordan (2005) indicated that changing established practices to new practices may be perceived as risky. In the model, the variable (risky) had a negative and statistically significant effect on the model $(P=$ 0.074 ) (Table 5). This indicates that growers who perceive converting to sustainable practices as risky are less likely to adopt certification. This result concurs with Kalogeras et al. (2006) and indicates that these growers are not yet willing to accept what they perceive as the higher degree of risk associated with converting to a sustainable production system. Likewise, growers may view becoming certified as risky as a result of their lack of knowledge about the relatively young U.S. certification programs and the steps involved in becoming certified.

Economic viability. Growers' desire for objective industry research on how certification can increase profitability (objres) had a
Table 4. Descriptive statistics of certification perception variables.

\begin{tabular}{lcc}
\hline Variable & Mean & SD \\
\hline risky & 3.54 & 1.66 \\
captinvst & 4.24 & 1.28 \\
noprofit & 4.04 & 1.76 \\
objres & 3.81 & 1.39 \\
usestpr & 0.63 & 0.49 \\
\hline
\end{tabular}

positive and statistically significant effect on certification adoption $(P=0.021)$ (Table 5). However, the perception that becoming sustainable will not generate profits (noprofit) for the operation had a negative and statistically significant effect on growers' interest in certification $(P=0.033)$ (Table 5). The cost of certification also presents an obstacle to adoption. When asked on a 5-point Likert scale, with 1 being no effect and 5 being a significant effect, growers indicated that paying up to $\$ 5000$ for certification had a significant effect on their decision to become certified ( $\bar{x}: 4.24)$ (Table 4), although this variable (captinvst) $(P=0.228)$ was not statistically significant (Table 5). Although growers currently perceive that adoption of sustainable practices will not generate additional profits for their operation, growers may be waiting to determine if adopting sustainable floriculture certification will indeed be profitable. Therefore, they would like to see objective industry research on how certification could assess more accurately if taking the next step, becoming certified, is worth their time, energy, and resources, consistent with Cary and Wilkinson's (1997) findings. 
Table 5. Regression coefficients of logistic regression model.

\begin{tabular}{|c|c|c|c|c|}
\hline Variables $^{z}$ & $\begin{array}{c}\text { Estimated } \\
\text { coefficient }(\beta)\end{array}$ & $\mathrm{SE}$ & $\mathrm{P}\{|\mathrm{Z}|\}>\mathrm{Z}$ & $\begin{array}{l}\text { Log odds of } \\
\text { adopting }^{y}\end{array}$ \\
\hline Constant & 3.278 & 1.628 & 0.044 & 26.519 \\
\hline risky* & -0.321 & 0.180 & 0.074 & 0.726 \\
\hline captinvst & -0.285 & 0.237 & 0.228 & 0.752 \\
\hline noprofit** & -0.341 & 0.160 & 0.033 & 0.711 \\
\hline objres** & 0.524 & 0.227 & 0.021 & 1.690 \\
\hline usestpr & -0.343 & 0.559 & 0.539 & 0.710 \\
\hline allretail** & -1.521 & 0.614 & 0.013 & 0.219 \\
\hline allwhole & -0.784 & 0.541 & 0.147 & 0.456 \\
\hline custoth** & -1.060 & 0.523 & 0.043 & 0.346 \\
\hline age & -0.340 & 0.540 & 0.529 & 0.711 \\
\hline sizeg15 & -0.914 & 0.668 & 0.171 & 0.401 \\
\hline highschool & 1.160 & 1.331 & 0.384 & 3.189 \\
\hline
\end{tabular}

${ }^{\mathrm{z}} \operatorname{Prob}(\mathrm{Y}=1)$ : interested in becoming a certified sustainable floriculture grower.

${ }^{\mathrm{y}}$ The log odds of adopting are the marginal effects of binary variables in discrete choice models.

**, *Significance level at $P \leq 0.05$ and 0.10 , respectively.

Prior experience. Previous studies have found that prior participation in similar production or technology schemes may positively influence a grower's perception of new technologies and practices (Barreiro-Hurle et al., 2008; Wilson, 1997; Wilson and Hart, 2000). It was expected that floriculture growers who had adopted at least one sustainable practice in their operation would be more receptive to pursuing certification. However, in this model, adopting at least one sustainable practice in the operation (usestpr) $(P=0.539)$ had no effect on the adoption of certification, because it was not statistically significant (Table 5). Only $13.5 \%$ of growers who have adopted sustainable practices are interested in certification. It is unknown why so few growers who have adopted sustainable practices are interested in certification. It could be the result of lack of demand from consumers for the certification label. If there is a lack of demand by the consumer, then there is little incentive for the grower to become certified as sustainable, especially if the certification is an additional expense to the operation.

Customers. Conversations with Veriflora ${ }^{\circledR}$ certified growers indicated that their large and influential customers motivated them to become sustainable and then to become certified. When the variables allretail, allwhole, and custoth were added to the model in comparison with cash and carry customers, only the growers who sold to retailers, landscapers, independent garden centers, and other venues were statistically significant $(P=0.013$ and $P=0.043$, respectively) (Table 5). Cash and carry customers differ from other customer types in that the end consumer physically visits the operation to purchase floriculture products, whereas the other customer types serve as an intermediary between the grower and the end consumer. Interestingly, all three customer groups had a negative influence on a grower's interest in adopting sustainable floriculture certification compared with cash and carry customers. The likelihood that growers who sell to retailers will adopt certification is 0.219 or approximately two to eight odds of adopting certification (Table 5). Likewise, growers who sell to landscapers, farmers markets, independent garden centers, and other small venues have a likelihood of adoption of 0.346 (Table 5). Reasons for this negative effect on a grower's adoption of sustainable practices is unclear; however, it may possibly be the result of lack of demand from these larger intermediary customer groups. In a retail setting, retailers may not have end consumers demanding sustainably grown products; thus, the retailers themselves are not demanding sustainable products from growers. This same effect may also be occurring with other direct markets, including farmers markets, independent garden centers, and landscapers. This lack of demand by the end consumer may be the result of limited understanding or awareness of sustainably grown floriculture products. There is also a possibility that the end user may be more interested in the aesthetic appeal of the floriculture products rather than the production aspects of the product.

The production and financial risks associated with the conversion to certified sustainable practices may also be a barrier to adoption by growers. Risk aversion is a common barrier to adoption of agricultural practices, slowing adoption rates because individuals, facing choices with comparable returns, tend to choose the less-risky alternative (Friedman and Savage, 1948; Huijsman, 1986). Likewise, changing established practices to new practices may be perceived as risky (Jordan, 2005). Shifting to a sustainable production system requires a strategic reorientation of the operation's organizational structure and goals, a possible dramatic allocation of economic resources, and a willingness to accept a higher degree of risk (Kalogeras et al., 2006). Three studies have found that a grower's concerns about the profitability and economic viability of new sustainability practices served as barriers to adoption (Cary and Wilkinson, 1997; Hattam, 2006; Kalogeras et al., 2006).

Prior participation in similar production or technology schemes may positively influence the grower's perception of new technologies and practices (Barreiro-Hurle et al., 2008; Wilson, 1997; Wilson and Hart, 2000). Barreiro-Hurle et al. (2008) found that once a grower shifted toward environmentally friendly practices, these practices tended to prevail over the long term if maintained. Therefore, floriculture growers who have adopted at least one sustainable practice in their operation may be more receptive to adopting additional sustainable practices and pursuing certification.

Existing relationships with buyers can influence the grower's production practices. Several Veriflora ${ }^{\circledR}$-certified growers indicated that large and influential customers have approached them about becoming sustainable and thus motivated them to become certified (personal communication with Veriflora ${ }^{\circledR}$-certified growers). Certified growers stated that it is important to have an established market before pursuing the certification process (personal communication with Veriflora ${ }^{\circledR}$-certified growers). Therefore, it is unknown what influence customer type will have on a grower's interest in certification. It is assumed that if a large customer desires certification, the grower will undergo certification to retain the business.

Previous studies have examined the role of age and operation size on certification or new practice adoption. Three studies have found that the adoption of new practices such as conservation programs or organic production was negatively influenced by an increase in the grower's age yet positively influenced by education levels (Barreiro-Hurle et al., 2008; D'Souza et al., 1993; Hattam, 2006). Growers with an educational background beyond high school tended to have higher adoption rates and tend to better understand the new technologies (Barreiro-Hurle et al., 2008; D'Souza et al., 1993). Higher education levels appear to give growers the ability to understand environmentally intensive programs involving technology and new information. Conflicting results were reported in past studies that examined the effects of operation size on adoption of environmentally friendly programs (Bonnieux et al., 1998; D'Souza et al., 1993; Wilson, 1997). Therefore, it is expected that amongst floriculture growers, growers with education levels greater than high school will be more likely to adopt sustainable practices and that operation size will not have an effect. Based on the literature, risk, economic viability, prior sustainability experience, and demographics can have a significant impact on adoption of certified sustainable floriculture programs.

\section{Conclusions}

Growers are very aware of sustainability and feel that it is important to the environment, because many have adopted sustainable practices in their operations. However, when taking the next step to become certified as a sustainable floriculture grower, growers have very little knowledge about U.S. certification programs and the majority is not interested in certification. The perception of sustainable practices as risky and that adoption of sustainable practices will not generate profits for the operation negatively impacted growers' certification interest. However, objective industry research in regard to certification and profitability potential would increase certification interest. Growers who 
have retailers, landscapers, farmers' markets, independent garden centers, and other small venues as customers are less likely to be interested in certification compared with those that have cash and carry customers. It appears that the lack of knowledge about certification and lack of incentive to adopt underlie these barriers. If end consumers are unaware of the availability of certified sustainable floriculture products and are not demanding the products, retailers, landscapers, and independent garden centers will not demand certified products from the grower. Likewise, growers may view becoming certified as risky as a result of their lack of knowledge about the U.S. certification programs and the steps involved in becoming certified. However, growers desire objective industry research as to how certification could increase their profitability. These attitudes indicate that growers would like to know if taking the next step, becoming certified, is worth their time, energy, and resources. Additionally, the desire for objective research may signify that growers need to know if consumers are willing to pay more for sustainable production practices, thus potentially increasing their profitability.

Interestingly, the findings in this study have similarities to the organic industry. These similarities may be the result of growers adopting organic practices as the best production alternative to conventional methods while pursuing sustainable practices. Organic growers acknowledge that there is a significant amount of risk associated with the transition to organic production as a result of the high input, certification, labor costs, production risks, and the difficulties in obtaining price premiums for their products (Hanson et al., 2004; Walz, 2002). Certified organic production risks are often offset by the attainment of premium pricing (Hanson et al., 2004), which is becoming more difficult to attain because of the entry of large-scale operations into organic markets (Walz, 2002). Therefore, growers may desire objective research on profitability from certification to see if the same condition would hold true in floriculture. This would be especially important because currently $59 \%$ of the U.S. Veriflora ${ }^{\circledR}$-certified growers are in the top 100 U.S. growers list (Veriflora ${ }^{\circledR}, 2009$; Yanik, 2009). Currently, $80 \%$ of the organic vegetable, floriculture, mushroom, and honey is sold at direct markets followed by wholesale markets $(69 \%)$ and direct to retail markets $(54 \%)$ (Walz, 2002). Because these local markets comprise the majority of the demand for organic products, the negative influence of these markets on the floriculture grower's interest in certification seems to indicate that there may be a lack of demand at these markets for sustainably grown floriculture products. The need to educate consumers on production practices is evident in both the organic and sustainable markets and may be the cause for the lack of demand for sustainably grown floriculture products.

Although these findings represent opinions of 112 growers and cannot be projected to all floriculture operations, this research provides information useful to growers and industry educators about the current perceptions of sustainable floriculture certification. Further research would be useful to evaluate how the availability of incentives for a grower to adopt sustainable floriculture certification influences adoption rates. Based on these findings, growers seek information on how certification will affect profitability. Growers need educational assistance from Extension personnel as well as industry experts to decrease the production and marketing risk of converting to this newer technology and understand U.S. certification programs. Additionally, consumer education on U.S. certification programs is needed to stimulate a "pull" demand strategy for sustainable floriculture certification.

\section{Literature Cited}

Annou, M.M., E.J. Wailes, and M.R. Thomsen. 2005. A dynamic decision model of technology adoption under uncertainty: Case of herbicideresistant rice. J. of Agr. and Appl. Econ. 37: 161-172.

Banerjee, S., S.W. Martin, R.K. Roberts, S.L. Larkin, J.A. Larson, K.W. Paxton, B.C. English, M.C. Marrar, and J.M. Reeves. 2008. A binary logit estimation of factors affecting adoption of GPS guidance systems by cotton producers. J. Agr. Appl. Econ. 40:345-355.

Barreiro-Hurle, J., M. Espinosa-Goded, and P. Dupraz. 2008. Does intensity of change matter? Factors affecting adoption in two agri-environmental schemes. Presented at 107th EAAE Seminar, Seville, Spain. 29 Jan. to 1 Feb. 2008. 5 Nov. 2009. <http://purl.umn.edu/6458>.

Bauer, A. 2007. Going green. Florists' Review. 5 Nov. 2009.<http://www.floristsreview.com/main/ june/featurestory.html $>$.

Bonnieux, F., P. Rainelli, and D. Vermersch. 1998. Estimating the supply of environmental benefits by agriculture: A French case study. Environ. Resour. Econ. 11:135-153.

Botts, B. 2007. Beauty and the plastic beast. Chicago Tribune online, 9 Oct. 2007. $<\mathrm{http}: / /$ www.chicagotribune.com/news/local/ nearwest/chi-0610plastic_jpjun10,1,5806552 . story>.

Bulut, H. and J.D. Lawrence. 2007. The value of third-party certification of preconditioning claims at Iowa feeder cattle auctions. J. Agr. Appl. Econ. 39:625-640.

Cary, J.W. and R.L. Wilkinson. 1997. Perceived profitability and farmer's conservation behavior. J. Agr. Econ. 48:13-21.

D’Souza, G., D. Cyphers, and T. Phipps. 1993. Factors affecting the adoption of sustainable agricultural practices. Agricultural and Resource Economics Review 22:159-165.

Delmas, M.A. and L.E. Grant. 2008. Eco-labeling strategies: The eco-premium puzzle in the wine industry. Proc. XII Amer. Assn. of Wine Econ. UC Santa Barbara: Institute for Social, Behavioral, and Econ. Res. 5 Nov. 2009. <http://www. wine-economics.org/workingpapers/AAWE_ WP13.pdf $>$.

Dillman, D.A. 2007. Mail and Internet surveys: The tailored design method. 2nd Ed. John Wiley \& Sons, Hoboken, NJ.

Fair Labeling Organization International. 2008. Fairtrade Labeling Organization International. 5 Nov. 2009. <http://www.fairtrade.net/>.

Fernandez-Cornejo, J., C. Hendricks, and A. Mishra. 2005. Technology adoption and off-farm house- hold income: The case of herbicide-tolerant soybeans. J. Agr. Appl. Econ. 37:549-563.

Fischer, C.F., Aguilar, P. Jawahar, and R. Sedjo. 2005. Forest certification: Toward common standards? Discussion paper 05-10, Resources for the FutureWashington, DC. $<\mathrm{http}: / / \mathrm{www}$. rff.org/RFF/Documents/RFF-DP-05-10.pdf>

Friedman, M. and L.J. Savage. 1948. The utility analysis of choices involving risk. J. Polit. Econ. 56:279-304.

Garson, G.D. 2009. Logistic regression. 5 Nov. 2009. <http://faculty.chass.ncsu.edu/garson/ PA765/logistic.htm>.

Gillespie, J. and D. Lewis. 2008. Processor willingness to adopt a crawfish peeling machine: An application of technology adoption under uncertainty. J. Agr. Appl. Econ. 40:369-383.

Gillespie, J.M., C.G. Davis, and N.C. Rahelizatovo. 2004. Factors influencing the adoption of breeding technologies in U.S. hog production. J. Agr. Appl. Econ. 36:35-47.

Greene, C. 2001. U.S. organic farming emerges in the 1990s: Adoption of certified systems. U.S. Department of Agriculture, Econ. Res. Service, Agriculture Information Bulletin No. 770, Washington, DC, 5 Nov. 2009. <http://www. ers.usda.gov/Publications/AIB770/>.

Greene, C. and A. Kremen. 2003. U.S. organic farming in 2000-2001: Adoption of certified systems. U.S. Department of Agriculture, Econ. Res. Service, Agriculture Information Bulletin No. 780, 5 Nov. 2009. <http://www. ers.usda.gov/publications/aib780/aib780.pdf>.

Hanson, J., R. Dismukes, W. Chambers, C. Greene, and A. Kremen. 2004. Risk and risk management in organic agriculture: Views of organic farmers. Renewable Agr. and Food Systems 19:218-227.

Hattam, C. 2006. Adopting organic agriculture: An investigation using the theory of planned Behaviour. Poster presented at Intl. Assn. of Agr. Econ. Conference, Gold Coast, Australia, 12-18 Aug. 2006. 5 Nov. 2009. <http://purl. umn.edu/25269>.

Huijsman, A. 1986. Choice and uncertainty in a semi-subsistence economy. A study of decision making in a Philippine village. $\mathrm{PhD}$ Diss., Wageningen Univ., Wageningen, The Netherlands. Abstr. 1081.

Jordan, J.L. 2005. Farmer's choice of using sustainable agricultural practices: A social capital approach. Presented at the Southern Agr. Econ. Assn. Annu. Mtg. Little Rock, AR, 6-8 Feb. 2005. 5 Nov. 2009. <http://purl.umn.edu/35505>.

Kalogeras, N., J.M.E. Pennings, and P. Garcia. 2006. What drives strategic behavior? A framework to explain and predict SME's transition to sustainable production. Presented at Amer. Agr. Econ. Assn. Annu. Meeting, Long Beach, CA, 23-26 July 2006.

Khanna, M. 2001. Non-mandatory approaches to environmental protection. J. Econ. Surv. 15: 291-324.

Krug, B.A., S.E. Burnett, J.H. Dennis, and R.G. Lopez. 2008. Growers look at operating a sustainable greenhouse. GMPro 28:43-45.

Liao, T.F. 1994. Interpreting profitability models: Logit, probit, and other generalized models. Sage Publications, London, UK.

Lifestyles of Health and Sustainability. 2009. 5 Nov. 2009. <http://www.lohas.com/>.

Lohr, L. 1998. Implications of organic certification for market structure and trade. Amer. J. Agr. Econ. 80:1125-1129.

Lopez, R.G., S.E. Burnett, J.H. Dennis, and B.A. Krug. 2008. 8 Steps to take to become sustainable. GMPro. 28:26-29, 50. 
Milieu Project Sierteelt. 2009. 5 Nov. 2009. $<$ http://www.my-mps.com/>.

Paudel, K.P., W.M. Gauthier, J.V. Westra, and L.M. Hall. 2008. Factors influencing and steps leading to the adoption of best management practices by Louisiana dairy farmers. J. Agr. Appl. Econ. 40:203-222.

Rogers, E.M. 1962. Diffusion of innovations. The Free Press, New York, NY.

Stewart, A. 2007. Flower confidential: The good, the bad, and the beautiful in the business of flowers. Algonquin Books of Chapel Hill, Chapel Hill, NC.

USDA. 2008. Floriculture crops briefing room [archived]: Floriculture crops background; market outlook, trade and policy. 5 Nov. 2009.
$<$ http://www.ers.usda.gov/Briefing/Archive/ Floriculture/>.

USDA. 2009. 2007 Census of agriculture: United States: Summary and state data. 1(51). 5 Nov. 2009. <http://www.agcensus.usda.gov/ Publications/2007/Full_Report/usv1.pdf>.

Veriflora ${ }^{\circledR}$. 2009. About the program. 5 Nov. 2009. $<$ http://www.veriflora.com/default.asp $>$.

Walz, E. 2002. Final results of the fourth national organic farmers' survey: Sustaining organic farms in a changing organic marketplace. Organic Farming Research Foundation, Santa Cruz, CA, 5 Nov. 2009. <http://ofrf.org/publications/ survey.html>.

Ward, C.E., M.K. Vestal, D.G. Doye, and D.L. Lalman. 2008. Factors affecting adoption of cow-calf production practices in Oklahoma. J. Agr. Appl. Econ. 40:851-863.

Wilkening, E.A. 1953. Adoption of improved farm practices as related to family factors. Madison, WI, Expt. Sta. Res. Bulletin 183.

Wilson, G. 1997. Factors influencing farmer participation in the environmentally sensitive area scheme. J. Environ. Manage. 50:67-93.

Wilson, G. and K. Hart. 2000. Financial imperative or conservation concern? EU farmers' motivations for participation in voluntary agrienvironmental schemes. Environ. Plan. A 32: 2161-2185.

Yanik, K. 2009. The top 100 growers: List \& index: 2009. Greenhouse Grower 27:7-11. 